\title{
Art-for-Peace in Ambon: An Intersectional Reading
}

\author{
Wening Udasmoro and Rahel Kunz
}

\begin{abstract}
In the context of the focus on 'everyday peacebuilding', the field of peace and conflict is increasingly interested in the use of art as a tool for peacebuilding. Feminist contributions emphasise the important gender dimensions of art-for-peace processes, but so far intersectional dynamics have received less attention. The aim of this chapter is to bring the interdisciplinary feminist literature into dialogue with insights on the intersectional dynamics of (everyday) peacebuilding and so propose a critical reading of the intersectional dynamics of art-for-peace initiatives. We focus on the context of Ambon in Indonesia to analyse one particularly prominent art-for-peace initiative: the Paparisa Ambon Bergerak (РАB) collective. Our analysis draws on a combination of data: visual and literature (poems) artwork produced by the РАв collective, in-depth expert interviews with $\mathrm{PAB}$ representatives and local peacebuilding activists, and secondary literature on РАВ. Our analysis reveals the complex social power dynamics and individual and collective dimensions of art-for-peace activities.
\end{abstract}

It is in creativity, in the fashioning of self and world, that people find their most potent weapon against war.

NORDSTROM, 1997, 4

The process to build the connection and friendship and to visit each other, is as important as the art itself.

Interview with a founding member of Paparisa Ambon Bergerak, September 2020 
Even though it has been happening for a long time, the use of art to build peace has been attracting growing interest in the field of peace and conflict since the 199os. In the context of the increasing focus on 'internal wars' (Bergh and Sloboda, 2010), 'everyday peacebuilding' and the 'local turn' (Bleiker, 2009; Kim, Kollontai and Yore, 2016; Labor, 2018; Rizzolo and Schuler, 2003; Zelizer, 2003), scholars and practitioners acknowledge the potential of art to transform conflicts and build peace. They highlight the ways in which art initiatives can contribute to healing, building peaceful environments, stimulating creativity for peacebuilding and building bridges and bringing people together by valuing and harnessing differences to move beyond othering (Marshall, 2014). Thus, art plays an important role in peacebuilding.

Feminist contributions emphasise the gender dynamics of art-for-peace projects (Clery, 2014; Parker, 1984; Väyrynen, 2013). Yet in this literature, intersectional dynamics have received less attention. In this chapter, we bring this interdisciplinary feminist literature into a dialogue with insights on the intersectional dynamics of (everyday) peacebuilding, which in turn has paid less attention to art-based peacebuilding. Drawing on these insights, we propose a critical reading of the intersectional dynamics of art-for-peace initiatives.

We focus on the context of Ambon in Indonesia to analyse one particularly prominent art-for-peace initiative: the Paparisa Ambon Bergerak (РAB) collective. РАВ has received widespread praise for its contributions to peacebuilding in Ambon (Indonesia Development Forum, 2018). Existing studies of PAB focus mostly on its use of digital and social media to counter rumours and false information, and on its use of art-for-education and -peace (Bräuchler, 2019; Indonesia Development Forum, 2018; Manuputti, 2018). The gendered and intersectional dimensions of РАВ as an art-for-peace initiative have not yet been explored in detail.

Our analysis draws on a combination of data: visual and literature (poems) artwork produced by the PAB collective, in-depth expert interviews with members of РАВ and local peacebuilding activists (carried out between 2014 and 2O2O) and secondary literature on РАВ. ${ }^{1}$ The data for this article were collected in the context of the project Gender Dimensions of Social Conflict, Armed Violence and Peacebuilding. The project seeks to understand the role of gender in conflict cycles and peacebuilding in three Indonesian provinces (Aceh,

1 We would like to thank our interview partners. Interviews were conducted by Arifah Rahmawati, Christelle Rigual, Jemmy Talakua, Wening Udasmoro and Rahel Kunz. Interviews have been anonymised for confidentiality purposes. 
Maluku and East Java). The Maluku conflict was concentrated in Ambon City, located on Ambon, one of the 32 islands that make up the Maluku archipelago (Azca, 2006). It is in this context that the PAB art-for-peace initiative emerged in Ambon. We draw inspiration from Väyrynen, who proposes studying artwork as a 'method that allows a critical reading of the nation's identity politics in relation to war and collective trauma' (Väyrynen, 2013, 138). Jauhola, meanwhile, suggests a methodology that reads art as open-ended politics instead of offering stable interpretations of art (Jauhola, 2016). In our context, the analysis of artwork allows us to perform a critical reading of the intersectional dynamics of art-for-peace initiatives.

We also follow the call by Andrä to pay more attention to the ways in which 'intersections of class, gender, race, and sexuality come to matter in art as an approach to peace' (Andrä, 2020). We take a broad understanding of intersectionality as a lens that exposes both the multiple dimensions of identity that mediate individual experience and the broader intersecting power dynamics at work in art-for-peace initiatives (Kappler and Lemay-Hébert, 2019; Stavrevska and Smith, 2020). In our analysis, we focus on two dimensions. First, we investigate the ways in which gendered, ethnic, class and religious 'differences' are understood and mobilised in art-for-peace initiatives. Here, we draw on the logic of gender as a resource for peacebuilding, illustrating how it often intersects with other social dynamics. We illustrate how the PAB initiative is a site where 'differences' are explicitly mobilised as well as challenged and transformed for peacebuilding purposes. Second, we analyse the ways in which art-for-peace initiatives trouble and transform existing gender relations intersecting with other identity categories and broader power dynamics. We draw attention to the ways in which the logic of gender as identity works intersectionally in the РАВ initiative. In particular, our analysis finds two key contributions to peacebuilding in these art initiatives: the transformation of violent masculinities of young, mostly lower-class urban men, and the creation of spaces for expressing young women's voices and denouncing gender-based violence. We highlight how these intersect with, draw on, and are complicated by the colonial heritage in the context of Ambon. Yet while our analysis highlights the key contribution that $\mathrm{PAB}$ initiatives make to mobilising differences for peace, overcoming violence, and building bridges for an inclusive peace, we also point out some tensions that come with these transformations.

The next section reviews the literature and presents our conceptualisation of art-for-peace initiatives; section three provides a short background on conflict and peacebuilding in Ambon; section four presents the PAB initiative, before moving to an analysis of the intersectional dynamics of this initiative in sections five to seven and concluding in section eight. 
While art has been used widely and effectively as an instrument of peacebuilding, it is important to acknowledge that art is not inherently peaceful and can also be used to create and fuel conflict (Andrä, 2020; C. Baker, 2019; Bergh and Sloboda, 2010). Art can be used for mobilising people and resources for conflict, and disseminating ideologies of othering that contribute to conflict. During conflict, art can act as a morale booster or a diversion for the nonfighting population, as intimidation, or as torture (Bergh and Sloboda, 2010, 45). In the Indonesian context, arts have been used by the authorities to control people's ideology in the context of political conflict between Nationalists and Communists, most prominently during the New Order era under the Suharto presidency (1968-1998). Suharto controlled the arts performed by the Gerwani, a women's communist organisation, killed many dancers during the period 1965-1966 (Larasati, 2013 and 2019) and used arts to control women's sexuality, which was considered demonic (Wieringa, 1996 and 2002).

Yet art can also be used in more positive ways to contribute to conflict transformation and peacebuilding. This potential of art to transform conflict and build peace has been analysed in various contexts by scholars and practitioners from the fields of art and of peace and conflict (Andrä, 2020; Bräuchler, 2019; Clery, 2013; Marshall, 2014; Premaratna and Bleiker, 2010; Zelizer, 2003). These studies identify various forms that art-for-peace initiatives can take: as artistic products or artifacts; as training tools, for example through art education; as artistic processes and as social protest (Zelizer, 2003). Thereby, art works in various ways to build peaceful individuals and societies. It can transform cycles of violence and act as an 'antidote to violence' (Marshall, 2014, 38) at both the individual and the collective level. Art promotes creativity, releasing hormones related to feelings of connection and happiness, and contributes to healing, whereby the 'destructive force of life is changed into the creative force in art' (Marshall, 2014, 37). In artistic practice, differences are needed and celebrated; they are 'the source of new understanding, connection, and richness' (Marshall, 2014, 38). Thus, through art, people practice trusting and reconnecting to themselves and others, and opposed groups can be brought together to create something collectively (Rizzolo and Schuler, 2003). Finally, art-based initiatives can also act as a form of social critique (Smith, 2017), for example for protest and ideological mobilisation against a political regime (Mandal, 2003). Thus, artistic engagements for peacebuilding can make numerous contributions in terms of broadening the scope of peacebuilding to include hitherto marginalised peacebuilding activities, creating space for the inclusion of alternative voices, reintegrating societies divided by violence to resist 
exploitation and outside intervention, and building new identities (Bräuchler, 2019; Premaratna and Bleiker, 2010). Importantly, art-for-peace initiatives also provide sources of alternative imaginations: 'insights found within the creative arts [...] can contribute alternative understandings of conflict and possibilities for peace' (Clery, 2014, 211).

In Indonesia, arts and literature have been used by Indonesian artists to resist and oppose the power of the Suharto regime using irony and satire. Every decade creates its own movements, such as Gerakan Seni Rupa Baru (New Art Movement) in 1975, Semsar Siahaan drama in the 1980s and early 199os, and the youthful radicalism of the Taring Padi (Fang of the Rice-plant) collective in the late 199os (Vickers, 2013). In the 199os, many theatre groups challenged the violent and oppressive regime of Suharto, including Theater Koma with their satiric performances (Bodden, 2010). In post-conflict and post-tsunami Aceh, the performance of arts such as traditional dancing has been used for trauma healing (Twarog, 2010). In our analysis, we focus mostly on the ways in which $\mathrm{PAB}$ art-based initiatives contribute to moving beyond othering and separation processes, and to transforming identities and power dynamics crucial for building inclusive peace.

What has so far received little attention in the literature are the intersectional dynamics of art-for-peace initiatives. In our analysis of art-based peacebuilding, we bring insights from the feminist literature on art-for-peace together with insights from scholars who analyse the intersectional dynamics of (everyday) peacebuilding yet pay less attention to art. In the feminist literature on the links between art, peace and gender, there is a tendency to focus on how (violent) masculinities contribute to militarising societies, to contesting peace, or to remilitarising societies in post-conflict situations (Baker, 2019; Enloe, 200o; Tidy, 2015). Thus, Baker for example analyses how veteran masculinities in popular culture in Croatia (e.g. those associated with a veteran singer) contribute to reproducing the militarisation of society and contest (rather than foster) peace (Baker, 2019). Tidy provides an analysis of an American popular culture figure, illustrating the 'uneasy productive dualities' in the mobilisation of masculinity for anti-militarist ends and the reproduction of gendered power relations through reworked military masculinities (Tidy, 2015, 456). This reveals a general blind spot in the literature on gender, peace and conflict that tends to focus on violent masculinities and pays less attention to the various non-violent and peaceful forms of masculinities that are involved in everyday conflict transformation and peacebuilding (Kunz, Myrttinen and Udasmoro, 2018).

Yet some feminist research in peace and conflict studies has analysed the ways in which non-violent masculinities and the transformation of gender 
dynamics more broadly are part of art-based peacebuilding. Väyrynen analyses how, in the context of Finland, visual art contributes to resistance to hegemonic masculinities and provides alternative masculinities for tackling trauma in a post-conflict context (Väyrynen, 2013). The literature on art education and therapy highlights how gender identities can be transformed through art (Baker et al., 2019) and how spaces for silenced voices can be opened up. For example, a study based on the experience of gender-specific art programmes in a mental health care centre in the Netherlands finds that art therapy 'can contribute to posttraumatic transformation and to a redefinition of masculinity' (Baljon, 2011, 151). In this context, art allows men to discover that it is possible to develop forms of masculinities that are not associated with aggression and destruction but are centred on creation. In the context of Indonesia, Larasati emphasises embodied and non-verbal means of trauma healing through art that challenge Western-centred psychology approaches (Larasati, 2013; 2019; see also Smith, 2007). In the context of post-conflict Aceh, Free Aceh Movement members, who used violence during the conflict, started to use art as a mechanism for maintaining peace in Aceh and creating non-violent masculinities (Kunz, Myrttinen and Udasmoro, 2018). Art-based activities thus seem a very powerful way to transform ideas and practices of masculinity, heal trauma and build peaceful relationships. ${ }^{2}$

We draw on this literature and combine it with insights on the intersectional dynamics of peacebuilding. This literature emphasises the ways in which intersecting social dynamics of gender, class, ethnicity, age, religion, etc. shape conflict transformation and peacebuilding practices (Kappler and Lemay-Hébert, 2019; Rigual, Prügl and Kunz, forthcoming; Stavrevska and Smith, 2020). Various understandings of intersectionality exist. ${ }^{3}$ In this chapter, we draw on intersectionality as a lens to investigate both intersecting identity dynamics and social power dynamics present and/or explicitly mobilised in art-for-peace initiatives. As various scholars have noted, a broad understanding of intersectionality allows one to focus on the micro-macro continuum 'to view the individual experience as a specific translation of wider structures of disadvantage

2 We are aware of the fact that art can also contribute to reinforcing patriarchy, but this is not the focus of this chapter.

3 The origins of this concept are commonly attributed to the work of Crenshaw (1991) and Hill Collins (1993), aimed at ending discrimination against women and as a tool with which to question the assumption of woman as a unitary category. The concept was originally designed to theorise the complex forms of subordination of black women in the US (Davis, 2011; hooks, 2014). Yet intersectional analysis has a much broader base, ranging across multiple contexts in the global South and North, in part linked to anticolonial feminisms (Hancock, 2015; Mendoza, 2016). 
and privilege'. In this way, intersectionally shaped experience is understood 'as a peephole through which the "worlds" of violence and peace can be explored' (Kappler and Lemay-Hébert, 2019).

While there are few explicit intersectional analyses of art-for-peace projects so far, various studies do analyse the intersection of various identity and power dynamics in art-for-peace initiatives. In Textiles Making Peace, Andrä acknowledges the importance of focusing on the intersectional dynamics of art-forpeace and surveys studies that reveal how in post-conflict situations 'needlework can serve to remake individuals' sense of self and the social fabric of communities' (Andrä, 2020, 6). This was the case for example in post-conflict Peru, where indigenous women testified to the Truth and Reconciliation Commission by means of the arpillera $^{4}$ (Franger, 2014). In her analysis of artbased projects in ex-Yugoslavia, Schroer-Hippel shows how men's stitching activities in public squares in Belgrade contributed to deconstructing ideas regarding hegemonic masculinities and proposing more peaceful forms of masculinity (Schroer-Hippel, 2016). This illustrates the intersectional dynamics of the use of textiles for peacemaking, whereby textiles can be used to denounce and mend intersecting gendered and colonial relations for example (Andrä, 2020). Yet Andrä also points out the double-sidedness of textile-for-peace initiatives, which can reproduce gendered and racialised understandings of textile art and thus be 'employed to make or break colonial framings and relations' (Andrä, 202O, 5). Focusing on Northern Ireland and Australia, Pruitt analyses the ways in which youth are involved in music-based peacebuilding in order to transform conflicts, for example by 'challenging racial and gender inequality, poverty and community violence' (Pruitt, 2013, xiv). In the context of Fiji, Clery analyses the ways in which art initiatives contribute to peacebuilding by creating safe spaces for dialogue, communicating messages of peace, and engaging communities in imagining possibilities for peace (Clery, 2013). In this context, arts-based approaches to peacebuilding address various intersecting themes, such as 'family and gender-based violence, religious and interdenominational conflict, racism, homophobia, and issues of stigma surrounding mental health and wellbeing' (Clery, 2013, 1).

These analyses show how art-for-peace initiatives have the potential to challenge intersectional power relations, bridge differences, and provide

4 Arpilleras are brightly-coloured patchwork pictures, stiched on a background of sack cloth, often made by women. They became a popular instrument to document and denounce oppression during the military regime of Augusto Pinochet in Chile in the 1970s and 1980s. See https://stitchedvoices.wordpress.com/2018/04/29/what-is-an-arpillera/ (accessed on 29 April 2021). 
alternative narratives and practices of peacebuilding. They also illustrate the potential tensions in art-for-peace projects, which can empower women but also reproduce intersectional discriminations. Drawing on these insights, this chapter focuses on the intersectional dynamics of art-for-peace initiatives in Ambon. We conceptualise art as an important site and instrument whereby intersectional dynamics are mobilised, visibilised, negotiated, contested and transformed.

\section{Conflict and Peacebuilding in Ambon}

The violent conflict in Ambon, in the province of Maluku (1999-2002) followed the fall of Suharto's New Order government, an authoritarian regime that had been in power for over thirty years. In Indonesian politics, the slogan 'Unity in Diversity' (Bhinneka Tunggal Ika) has been used by different political regimes to strengthen their power. "Bhinneka Tunggal Ika tan hana dharma mangrwa ${ }^{5}$ ' appears in a work of Mpu Tantular entitled Sutasoma. He was a very important author at the time of the Majapahit Kingdom (the second biggest of the kingdoms of the archipelago, 1293-1500). The slogan was used by Sukarno following independence to unite different religious and ethnic groups in Indonesia. Suharto also used the slogan, with the same aim. However, instead of respecting differences, in reality Suharto actively promoted the homogenisation of Indonesia, 'Javanising' it (i.e., imposing Javanese culture), using the bureaucracy and the military as tools to reduce the diversity of Indonesia, and controlling tensions among different groups through military power (Bhakti, Yanuarti and Nurhasim, 2009, 7; O'Rourke, 2002). The subsequent transition period spawned violence in different parts of Indonesia as jockeying for power between the New Order government and the Reformasi movement fuelled political chaos in many provinces (Trijono, 2002; van Kinken, 2007). Religious and ethnic divisions deepened as people in Aceh, Ambon, Kalimantan and Sulawesi held Javanese domination responsible for poverty and social injustice in these regions. Following the end of the 30-year Suharto regime, conflicts fuelled by suppressed tensions erupted all over Indonesia. In this context, the term 'diversity' had lost its appeal and other terms and slogans were used more frequently in the Reformasi era (see below).

Ambon experienced the bloodiest ethno-religious conflict during this transition to the Reformasi era. The flashpoint of the conflict was Ambon City.

5 Translation by the authors: 'Being different but still one, the truth is not ambiguous'. 
Violence was 'communal', pitting (Christian and Muslim) indigenous populations against (predominantly Muslim) immigrants (Bertrand, 2004; Schulze, 2017). Indigenous Ambonese-both Muslim and Christian-dominated in office work and other white-collar jobs, and were expected to find employment there (Sudjatmiko, 2008). In contrast, the mostly Muslim Buton, Bugis, and Makassar migrants dominated the transportation sector and also largely controlled trade in Ambon. They were able to draw on extensive and powerful economic networks, especially for manual labour. The violence pitted ethnic Ambonese and these immigrants against one another, but took on a religious overtone, in part as a result of Islamist influences from outside the region. The violence itself was triggered by a fight between two young men, a Christian from Mardika and a Muslim from Batu Merah, a neighbourhood of Ambon City (Azca, 2006). Yet to fully understand the emergence of the conflict in Ambon, one needs to consider its more structural and long-term foundations (Bräuchler, 2019). Ever since the arrival of the colonising powers religion has been politicised. Jakarta's push for the Islamisation of politics in the 1980s and 199 os also contributed to this. The demographic shift brought about by spontaneous (mainly Muslim) immigration and governmental transmigration programmes from the 1970s onwards increased existing tensions and competition in the job market. And the Indonesian security forces took sides in the violence in an attempt to maintain their power. Maluku also faced, and still faces, colonial and neo-colonial exploitation of its natural resources (Bräuchler, 2019, 204).

These outside interventions were also accompanied by the construction of dichotomous narratives regarding Ambon. In Indonesia, including Ambon, there exists a narrative that opposes the 'civilised' centre to the 'uncivilised' periphery (Irawanto, Ramsey and Ryan, 2011). Western Indonesians, most commonly represented by the Javanese, have been framed as having a higher culture and a more refined language, while eastern Indonesians are commonly stereotyped as violent and unrefined. This seems ironic, as history shows that political and cultural conflict, including military invasion, has more commonly been the tool of the Javanese. Take, for instance, the Majapahit Kingdom, which exerted its political, cultural and social influence over much of eastern Indonesia (Berg, 1974; Muljana, 1979) —including Ambon.

Nonetheless, such civilisation narratives act as cultural markers of Ambon even today (Sulistiyono and Rochwulaningsih, 2013). On the one hand, these narratives are influenced by the identity categories created by non-Ambonese, particularly the Javanese, representing the inhabitants of all the islands other than Java as 'Sabrang', literally meaning 'people across the sea'. From the Javanese standpoint, Sabrang people are considered uncivilised. The Javanese 
have continued to label these populations as outsiders and to stereotype them as violent and uncivilised, including through their wayang (shadow puppetry), which was used by the New Order regime (1968-1998) to reproduce Javanese hegemonic power. In wayang, those from Sabrang are stigmatised as anti-heroes and as violent monsters lacking etiquette (Sulistiyono and Rochwulaningsih, 2013). At the same time, the ideal of violent masculinity is reproduced within Ambonese society. What is perceived as 'aggressiveness' in this narrative is understood as 'straightforwardness' by the Ambonese and they claim this as part of their culture. In our interviews in Ambon, respondents would also reaffirm this narrative: 'Fighting is normal for the Ambonese. It is our habit' (interview with a village leader, 2014). This opinion is also underlined by a founding member of Ambon Bergerak: 'We've been in conflict since our ancestors. Conflict is in our culture, but when interventions come from outside then it becomes bigger' (interview with a founding member of Ambon Bergerak, September 2020). The playing out of aggressive masculinities can be observed, for example, on the football field, where fighting might break out between male youths after one group loses a match. Informants stated, however, that when such fights occurred, local elders would arrive and end the fighting (interview with a village leader, 2014). This illustrates the rich conflict management infrastructure in Ambon.

The people of Ambon have long-standing traditional cultural mechanisms for conflict management, thanks to which they have been successful in creating a harmonious society and in maintaining it a long time. These include a kinship system known as pela gandong, wherein two clans become allies, intermingle, and/or intermarry, thereby creating a strong bond between them. Such alliances are established across religious, ethnic or social affiliations. So, for instance, a friendship between a Muslim and Christian may, over time, evolve into an alliance between their clans and families. This mechanism has provided a cultural means of de-escalating conflict in Ambon, including conflict between families and communities. Traditional leaders and elders are particularly prominent, using pela gandong as a mechanism for reminding others of the kinship bonds that have united them for generations. Another common practice is panas pela, through which community elites meet among themselves to maintain peace. This mechanism, which occurs within a specific space known as baileo, has also offered the Ambonese a means of mitigating conflict (Wattimena, 2009). Such traditional cultural mechanisms have been maintained by the elders and adults of Ambon and they mostly involve senior men, who occupy culturally honoured positions in Ambon's Muslim and Christian communities. 
During the violent conflict in Ambon, such local mechanisms were used in an attempt to mitigate its effects, and they are still in use today. At the same time, new instruments were developed as youth groups sought other mechanisms. Youths from diverse backgrounds recognised that the media had contributed significantly to the expansion and escalation of the conflict-particularly the Java-based newspapers that were diffusing coverage of the conflict throughout Indonesia. In their coverage of the Ambon conflict, Javanese newspapers were biased and influenced by their specific religious affiliations (including, for example, in their reporting of stories that Christians had attacked Muslims or vice versa). Thus, young Ambonese sought to restrict these media outlets' right of entry, instead creating their own stories, which — for example-emphasised the restoration and normalisation of relations between villages. They named their movement 'provoking peace' (provokasi damai) (Rohman, 2019, 12).

\section{Paparisa Ambon Bergerak and Art-for-Peace}

Ambon is known as 'the city of music', and singing is commonplace in everyday Ambonese life. Indeed, many of Indonesia's most popular musicians have come from the city (and some have also been involved in art-for-peace initiatives). Young people in Ambon are very interested in all forms of art, and 'creative, pro-diversity movements' flourish (Tempo, 2018). Young people from diverse religious, ethnic, class and sociocultural backgrounds have started to meet regularly and established various initiatives to promote and maintain peace. Since 1999, many bloggers in Ambon have been promoting peace through their writings (Tempo, 2018). In 2007, the Maluku Photo Club, an interfaith community for young people interested in photography, was formed. Its members promote peaceful relationships across religious divides and diffuse photos that show the beauty and peacefulness of Ambon, with the aim of changing people's perceptions of Ambon as a conflict-torn city. In 2008, the Moluccan Hip-Hop Community (MHC) was founded (Tempo, 2018). Five years later, the \#SaveAru environmental campaign was to go viral on Twitter (Bräuchler, 2019).

From these pre-existing initiatives, in around 2010 Ambon Bergerak (Ambon on the Move) was born. Initially, the collective organised various activities in cafes and throughout the city. Since 2014, these have included regular crossregional art events named TrotoArt (sidewalk art). In 2015, thanks to funding from ICT Watch from Jakarta and from Ambonese supporters, some of whom had emigrated to the capital and wanted to support peacebuilding in Ambon, PAB moved to permanent premises in Sirimau District and became Paparisa 
Ambon Bergerak (the word paparisa translates as 'house') (interview with a founding member of $\mathrm{PAB}$, September 2020). Thus, PAB did not originate thanks to, and is not dependent on, government or international funding, in contrast to art-based projects initiated by the international community, whose activities are heavily controlled by external influence (including, for example, certain performance-healing initiatives in the context of post-conflict, posttsunami Aceh) (Twarog, 2010).

The underlying idea of РАВ is that creative activities will mend religiousrelated divisions and build peace in Ambon. An initiator of РАВ explained in an interview that the community is a 'home' for any group that opens dialogue and loves peace:

The beginning of the initiative, it was because we're all children of the 8 os. We had friends in our youth of all sorts, and the youth of 2008/2009, the children were living separately, and then in the end the youths had no friends of other religions. Maybe, at the time, our friends all felt the need to open space for people of different religions to meet. When the incident happened in 2011, we never talked about peace. We always thought about more than results; we always thought about our friendships. Our slogan was 'Community: It's all about friendship'. We wanted everyone to be friends first, so the barriers within could be torn down.

Interview with a founding member of PAB, July 2017

РАВ engages in many different activities, including blogging, film, hip-hop, theatre, music, painting, art exhibitions, street art activities, and classes on public speaking, the history of Ambon, and entrepreneurship. РАВ activities thus include all the forms of art initiatives identified above: artistic products or artifacts, training tools (including art education), artistic processes and social critique (Zelizer, 2003). All these activities bring together people from different backgrounds to build friendships, strenghten communities and build a culture of peace (interview with a founding member of PAB, September 2O2O). PAB initiatives resonate with global transformations, and with the broader movement of Indonesian 'street culture' resisting political violence, such as the post-tsunami and post-conflict punk culture in Aceh and in Indonesian urban culture in general (Heryanto, 2008; Jauhola, 2015). A few studies of PAB's activities have emerged. They focus mainly on its contributions to environmental activism, its innovative use of digital and social media for conflict prevention and transformation and its art-for-peace projects (Bräuchler, 2019; Irawanto and Octastefani, 2019; Manuputti, 2018; Rohman, 2019). We focus on the intersectional dynamics of the $\mathrm{PAB}$ art-for-peace initiatives. 


\section{$5 \quad$ 'Embracing Difference' as a Resource for Peacebuilding}

Post-conflict Ambon is characterised by segregation along religious (i.e., between Muslims and Protestants), ethnic (Ambonese and non-Ambonese) and class lines. Segregation has systematically transformed villages, hamlets, and even housing developments into enclaves. In its efforts to create and cultivate peace in Ambon and prevent future conflict, PAB found that such segregation precluded people from meeting, and aims to address this problem through its activities:

PAB has held many events in the streets, in cafes, and in other public spaces. Members have not only played music and read poetry, but also exhibited their artworks. They hope that, if people come, they will meet others whom they have not met since the conflict. They will bring together youths from various backgrounds, to promote intergroup interactions. Friendships will be rekindled, with $\mathrm{PAB}$ as the catalyst.

Interview with a local peacebuilding activist, September 2020

In its activities, $\mathrm{PAB}$ emphasises the importance and potential of embracing difference (interview with a founding member of PAB, September 2020). PAB itself consists of youths from various religious, ethnic, tribal and gender backgrounds, who all desire a sustainable peace in Ambon: 'Everyone is different. Every person has their own stories. The elderly guys, most of us, we were soldiers. We had different backgrounds. We met at school to build Paparisa Ambon Bergerak' (interview with a founding member of PAB, September 2020). The PAB collective does not use the term 'diversity', but instead refers to 'embracing difference, living together, friendship, community, pluralism', etc. Given the particular meaning that 'diversity' has taken in the context of use of the slogan 'unity in diversity' in Indonesia and given that PAB does not use the term, we also-as far as possible-refrain from using it in this chapter.

In their activities, PAB members consciously and positively draw on difference, including gender, religious, and ethnic differences. The photograph in Figure 4.1, for instance, includes members of РAB from various backgrounds posing as icons of peace. In the background (on the left), we can see a mural painting of two former child combatants: Ronald Regang and Iskandar Slamet. Having once fought in the name of Christianity and Islam, respectively, these two youths from lower-class families have become spokespersons for peace in Ambon and symbolise the importance of moving beyond differences, and productively mobilising difference for peace. These two child ex-combatants became peacebuilding agents after they stopped their violent activities thanks 


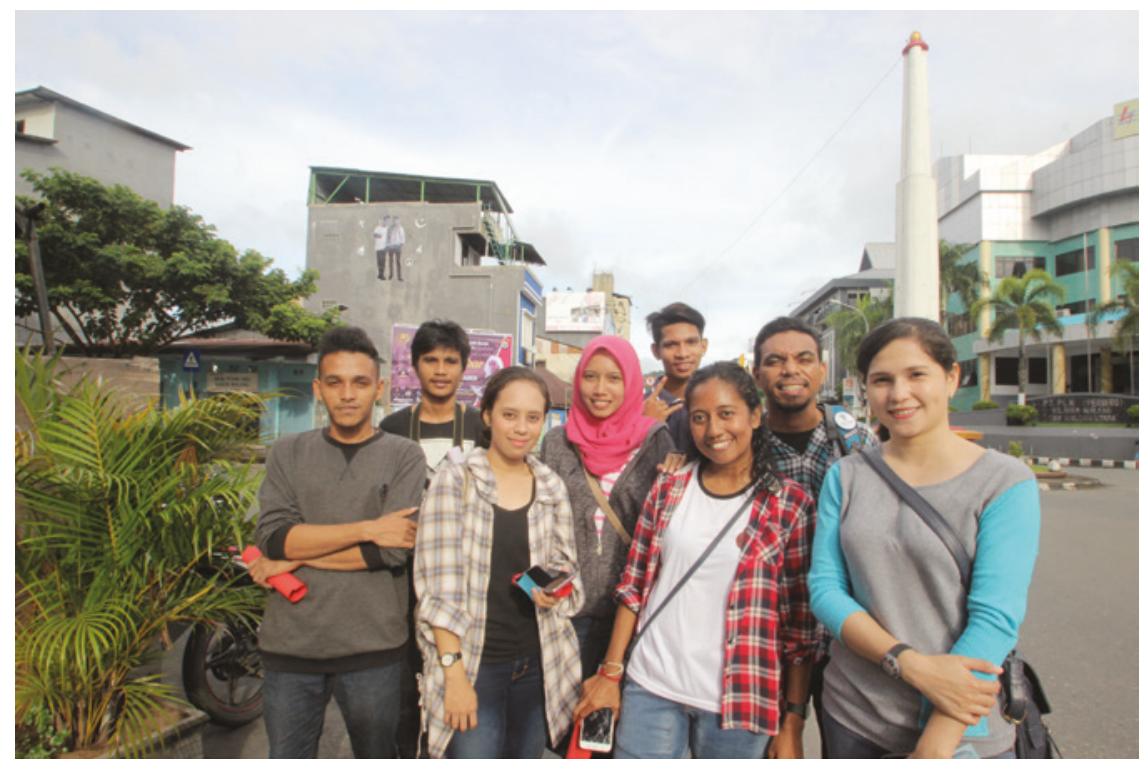

FIGURE 4.1 Members of РAB in front of the mural depicting two young ex-combatants who became peacebuilders SOURCE: PAB

to advice from a clergyman, Jacky Manuputty (interview with a former child combatant, November 2014).

In another illustration of the mobilising of differences as a resource for peacebuilding, the photo in Figure 4.2 features a group of young people in front of a mural created by РАВ to portray its ideal of intergroup harmony. Mural arts have often been used by urban youth as a way of resisting state norms and structures. In this context, however, Ambonese youths create murals to resist violence and conflict and to build peace. Indeed, these murals have become an important icon of peacebuilding in Ambon.

Figure 4.3 features а РАВ mural that promotes bringing together populations that were, after the conflict, no longer in contact with one another (interview with a founding member of $\mathrm{PAB}$, September 2020 ). This interactive mural unites people from different backgrounds through art, as explained by a founding member: 'talking about friendship, the hands here function as nameboards, as those who come are asked to write the name of a friend, one from a different religious background, whom they hadn't met in a long time, or with whom they'd lost contact owing to the conflict' (interview with a founding member of PAB, September 2020). 


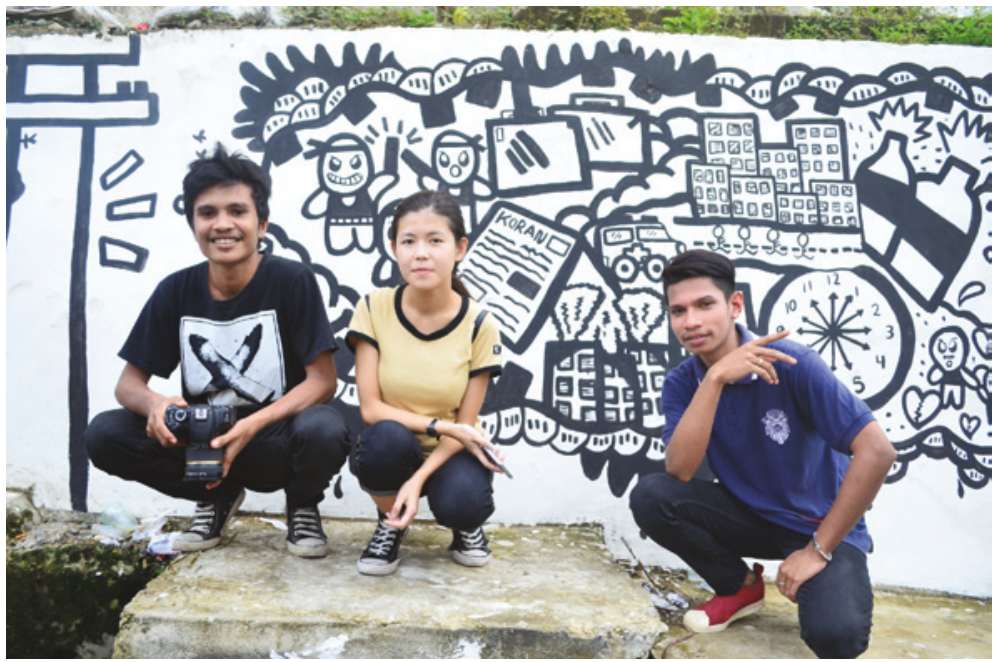

FIGURE 4.2 Art-for-peace mural

SOURCE: PAB

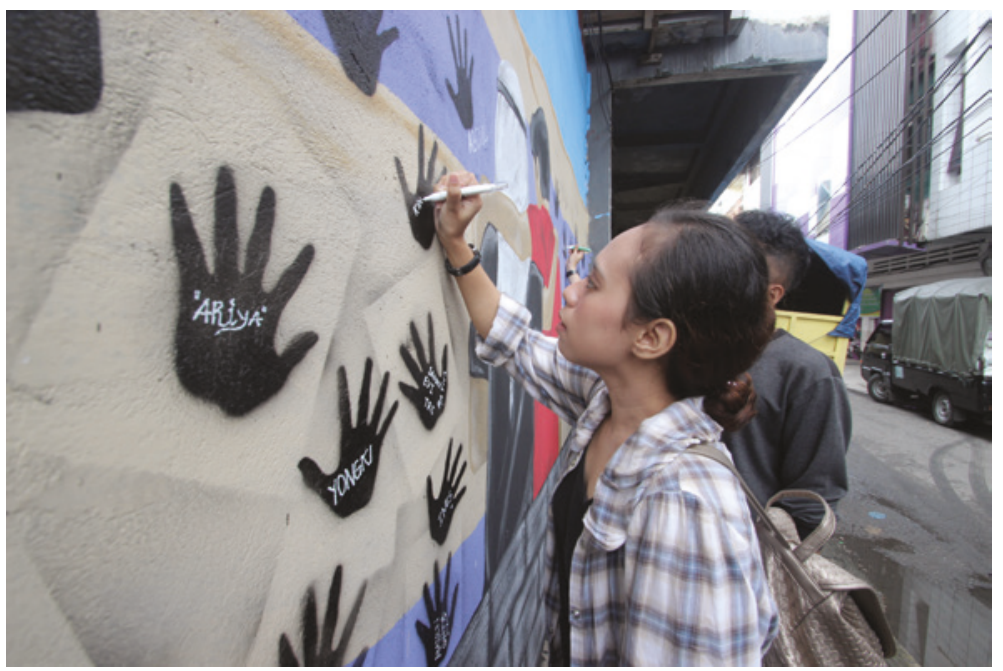

FIGURE 4.3 Artwork for building friendship SOURCE: PAB

Thus, the PAB collective is a site where 'embracing difference' is explicitly and successfully mobilised for peacebuilding. This is done through using art as a product, but also as an interactive process, educational tool, and site for social critique. Embracing difference and building friendship through art is 
its strategy for transforming gender, ethnic and religious performances in an effort to build peace, drafting new visions of identity and community. Thereby, differences are understood as a resource, and celebrated as 'the source of new understanding, connection, and richness' (Marshall, 2014, 38). Through its emphasis on 'embracing differences', PAB sheds light on the various intersecting identities that mediate art-for-peace initiatives. Beyond the focus on identity, we also read РАВ activities as sites where structural inequalities that contribute to the marginalisation of certain groups and individuals are revealed and mended. Using an intersectional lens allows us to draw attention to these contradictory ways in which differences are mobilised but also challenged and transformed, as the next section shows.

Peacebuilding and the Transformation of Identities

PAB initiatives not only mobilise various dynamics of differences in explicit ways for peacebuilding, they are also a site where these differences are negotiated and transformed. This happens in two main ways: through the transformation of masculinities and the opening of spaces for women's voices. Using art as a means of creating and cultivating peace in Ambon, РАВ has contributed to transforming and diversifying masculinities, from violent, military forms into non-violent forms. During the conflict, the movement's founders were aged between nine and sixteen, and many were child combatants (interview with a former child combatant, November 2014). These young men saw their involvement in the conflict as a means of defending their religion and their community. They felt compelled to participate, as otherwise they would not be considered 'men'. Thus, violent, militarised forms of masculinity were highly prevalent in Ambonese society. Yet men's experiences of, and involvement in, the conflict were also shaped by several other social categories, including class, age and ethnicity. With regard to social class, for instance, as in other conflict areas in Indonesia men from the lower middle classes were more likely to become combatants; upper-middle-class men, conversely, were more likely to be sent abroad (to Java, or another island) to avoid the conflict. Ethnicity was a similarly complex matter. Ambon is not only home to the ethnic Ambonese but also to a sizable Butonese, Buginese, and Makassarese diaspora as well as to migrants from across Indonesia (including Java). During the conflict, migrants - both male and female - were more likely to flee Ambon as they remained a marginalised minority. In terms of age, meanwhile, youths were more likely to become combatants. Older residents of Ambon tended to advise these combatants, or-conversely—to seek peace. 
PAB members recognise that the violence perpetrated during the conflict was an inappropriate means of resolving social issues. Their experiences with conflict left them traumatised, and thus they have sought ways of healing and promoting non-violent means of resolving conflict. Through art-based activities, they contribute to healing traumas and to transforming and moving away from violent forms of masculinity. They believe that, through art activities such as writing and reading poetry, playing music, and exhibiting their paintings, they will be able to transform dominant violent masculinities into non-violent ones. Thereby, the expression of bravery will be transformed from violent means of expression to expression through innovative art-for-peace projects and becoming agents for peace. As one founding member stated: 'We have a culture of Kabarasi: if you are brave, people will respect you' (interview with a founding member of $\mathrm{PAB}$, September 2020). A local peacebuilding activist explained:

These are men who reflect the common stereotypes of Ambonese men. But they recognised that violence couldn't solve problems. For that, they required something softer, art and culture for peace. Not violence, but creation. What kind of men are they now? These young men have transformed. Ambonese men have long been identified with violence, but now many of them avoid responding to things with arrogance. They are more refined, more polite, using poems as a language for representing their refinement. Before, they would use violence, but now they use a more feminine approach. So there has been a paradigm shift regarding violence.

Interview with a local peacebuilding activist, November 2020

What is interesting in this statement is the gendered dichotomy between a violent masculine approach and a peaceful, soft feminine approach (associated with poetry, for example). Through the РАв initiative, as masculinities are transformed and diversified, this dichotomy is to some extent reproduced but also destabilised. This is also illustrated in the somewhat gendered division of PAB activities, whereby male members tend to be more involved in rap music while female members are more present in poetry, for example. This illustrates the tensions inherent in РАв activities: they challenge and transform violent masculinities, yet risk reproducing gendered stereotypes in the process.

This negotiation and transformation of masculinities can also be observed in the artwork produced by РАв members. Various artistic creations express such contradictory messages. Take, for example, the poster presented in Figure 4.4, 


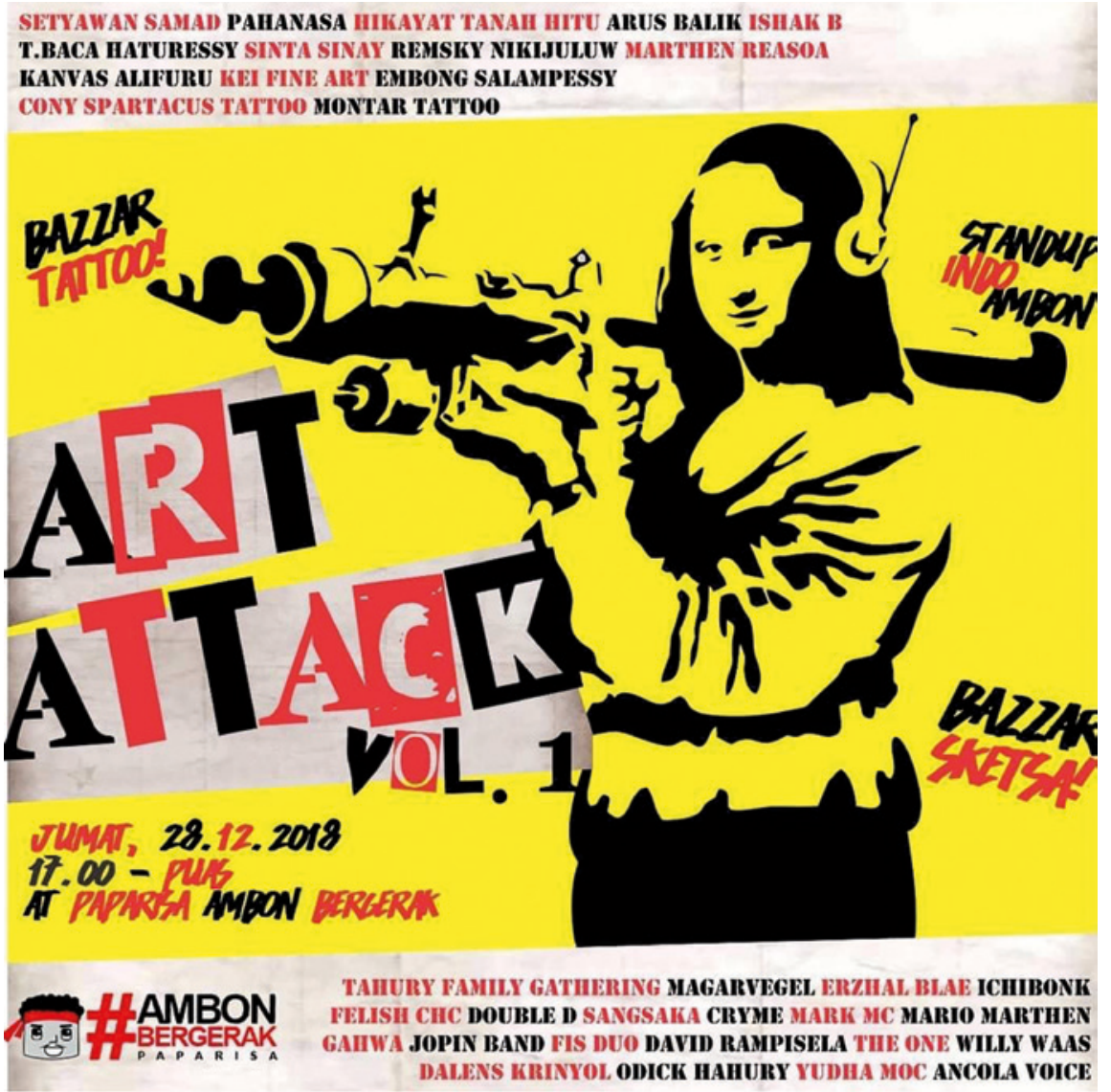

FIGURE 4.4 'Art Attack' poster

SOURCE: PAB

which was used to advertise an art exhibition called Art Attack Volume 1, held by РAв on 28 December 2018.

This event involved various activities, including a tattoo bazaar, a sketch workshop and a stand-up comedy performance. The poster features the Mona Lisa with headphones, and a rocket launcher on her shoulder. In our reading, this poster expresses some of the contradictions and transformations of masculinities in the context of РАВ art-for-peace activities. It features a Banksy version of the Mona Lisa. This resonates with developments in the global street art movement. ${ }^{6}$ A founding member of $\mathrm{PAB}$ confirmed that he was deeply

6 Mural and street art have a long history of being used to demand social change. They played an important role in the fall of Suharto and also recall the brick wall in post-industrial cultural critique in the UK context (Heryanto, 2008; Larasati, 2019). 
inspired by Banksy's mural art (interview with a founding member of PAB, November 2020). A member of $\mathrm{PAB}$ who was involved in designing the poster told us that his idea was to introduce the Ambonese art scene to the work of Banksy and to use this famous reference to represent the courage and bravery of using art-for-peace. He explained:

The young artists, we started a new event. We tried to come up with a different style (to be brave), so we came up with art attack. Mainstream art is boring so we encourage young artists to push their ideas. For the visual, I love Banksy (I'm a fan of him). I saw Mona Lisa there. Not all artists here know Banksy so I wanted to introduce Banksy. I was trying to encourage them.

Interview with a founding member of PAB, September 2020

This poster features symbols and words that can be interpreted as violent- - the use of the word 'attack' and the depiction of a rocket launcher/bazooka. This is also the case for other РАВ art creations, which often use terminology and symbols associated with violence and conflict. The poster is mostly bright yellow, with text in red and black, which can be interpreted as quite aggressive colours and understood as red blood coming out of the rocket launcher. At the same time, the headphones suggest that the Mona Lisa is listening to music. The poster portrays a violent form of activity, illustrated by means of a the rocket launcher. Yet it also disturbs gender stereotypes by portraying the Mona Lisa in this pose, giving an 'active' role to a woman we usually see seated.

We read this poster as an expression of the destabilisation and transformation of identities in the context of art-for-peace initiatives. It shows the complexity of the relationship between peace and conflict, disrupting dichotomies. It also illustrates the ways in which РАВ productively mobilises the dialectic between the persistent nature of conflict as part of Ambon society and as part of culture on the one hand (e.g., violent, direct language and pride in violent symbols, etc.) and the shift towards peaceful identities on the other (e.g., use of 'soft' language and attitudes, friendship and care, etc.). Thereby, $\mathrm{PAB}$ also contributes to countering the mainstream national media stereotype of Ambonese men as violent and aggressive, while reasserting the value of Ambonese history and culture.

In the bottom left corner of the poster, we find а РАв logo. The man in the red headband depicts the Moluccan hero Pattimura, who fought a heroic struggle against the Dutch colonial government. Pattimura was selected for his patriotism and his courage, both of which are symbolically associated with Ambonese men: 'The logo is Pattimura, someone that we all respect. If you go 
to Ambon, you will find Pattimura everywhere, because we are proud of him' (interview with a founding member of $\mathrm{PAB}$, September 2020). In that logo, Pattimura's headband is red: a colour associated with patriotism. 'The usage of the red headband symbolises the local wisdom. Moluccan men, they like wearing red headband as symbol of patriotism. When we struggle for something, we use the red headband as a symbol of patriotism' (interview with a peacebuilding activist, September 2020). РАВ sometimes also uses a similar feminine logo — an image of the Martha Christina Tiahahu, who also fought against the Dutch colonial government (interview with a founding member of $\mathrm{PAB}$, September 2020). In our reading, this resonates again with the efforts of $\mathrm{PAB}$ to transform the meaning and expression of 'bravery' in the context of violent forms of masculinities, a transformation leading towards peaceful, artistic expressions of masculinities. Thus, we read this poster as an illustration of efforts to transform violent masculinities associated with the conflict into peaceful, brave masculinities that express themselves through artistic means. Yet paradoxically, the poster could also contribute to renewing the image of violence associated with Pattimura's struggle and could thus contribute to reproducing acceptance of violent forms of masculinities in people's imaginaries (despite PAB's explicit renouncing and denouncing of violence). This shows again the potential tensions in art-for-peace initiatives.

Another РАВ initiative is entitled 'Poetry Hunt', a monthly meeting in which participants try to find poems scattered across the city (Figure 4.5).

The poster advertising the event uses various shades of dark grey and black, creating a dark and threatening atmosphere. Front and centre, it features a circular target, connoting hunting and shooting. In the background there is an old, partly destroyed corner of a wall with writing on it. The text is mostly hidden behind the target visual in the front, but the initial words of each line are visible. Some of these words suggest conflict and fighting and contribute to the dark atmosphere of the poster: 'damage', 'haunted', 'head', etc. But in practice, the poetry hunt is a playful activity that brings people together and gets them to move across the city in search of poems, going to parts of the city they have not visited before, illustrating the transformations that art-for-peace initiatives can bring about. Again, we can see how PAB activities to some extent play on and reproduce imagery associated with conflict and violence, yet with the aim of building peace. This contributes to challenging and complexifying dichotomies between conflict and peace.

Our analysis shows how РАВ activities contribute to transforming violent forms of masculinities into more peaceful, artistic forms. We can see how art works to negotiate, diversify and transform masculinities, yet this process is never smooth and creates tensions and sometimes also reproduces 


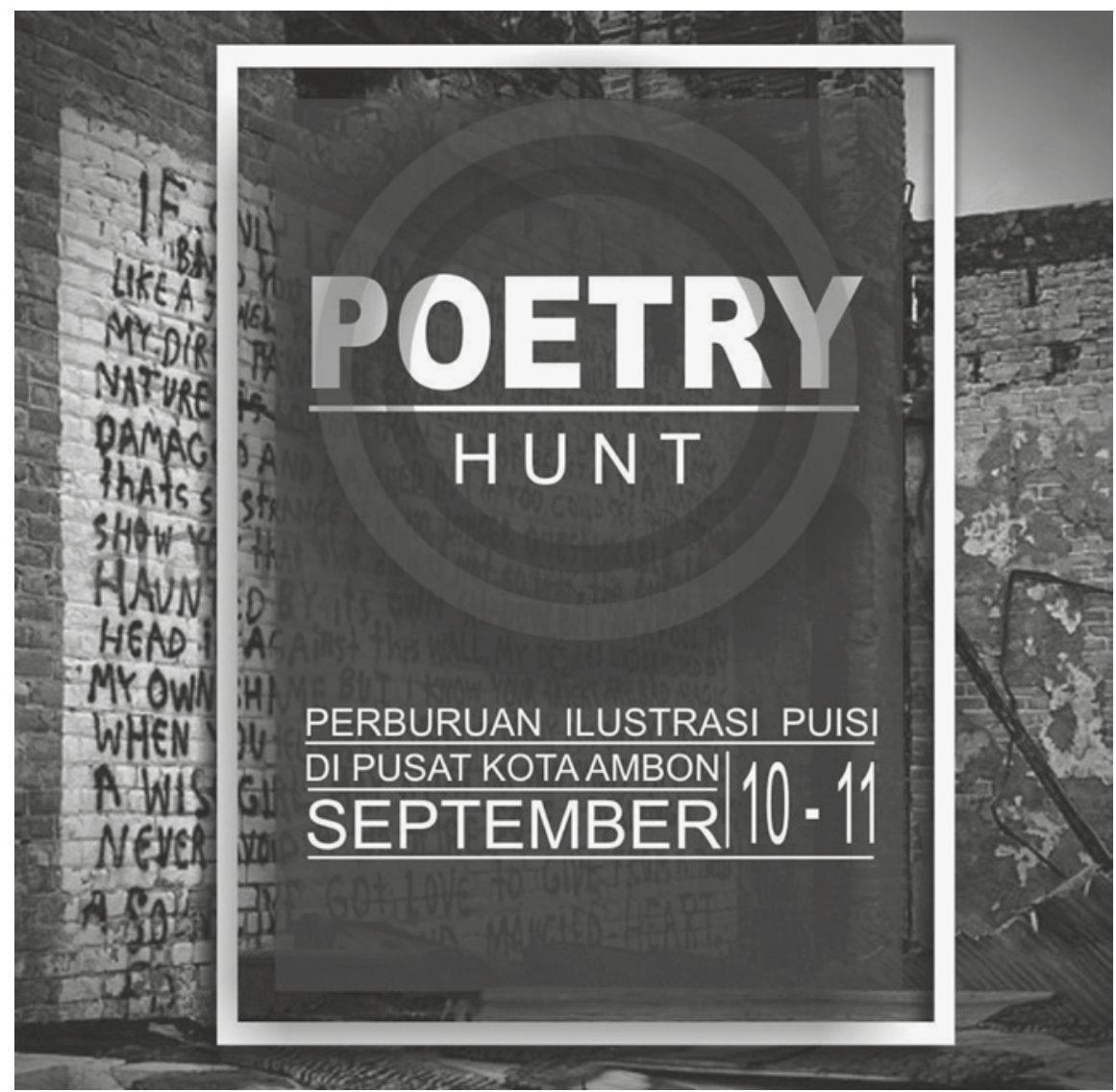

FIGURE 4.5 Poetry Hunt

SOURCE: PAB

gendered dichotomies. Through art activities, PAB also complexifies and destabilises dichotomies between peace and conflict, and between violence and non-violence. РАВ art initiatives bring into complex association (violent) anticolonial masculinity (and to some extent femininity) and the bravery of postconflict peacebuilding masculinity. We read these initiatives as revealing the intersections between forms of masculinity and the power dynamics of the region's colonial heritage. Thereby, art works not only as a form of healing of trauma and of mending of relationships, but also as a form of social critique, illustrating the open-ended politics of art. Yet art-for-peace initiatives often generate tensions. As illustrated in $\mathrm{PAB}$ art productions, art can be employed 'to make or break colonial framings and relations' (Andrä, 2020, 5). Moreover, the transformation of masculinities often produces complex results: certain 


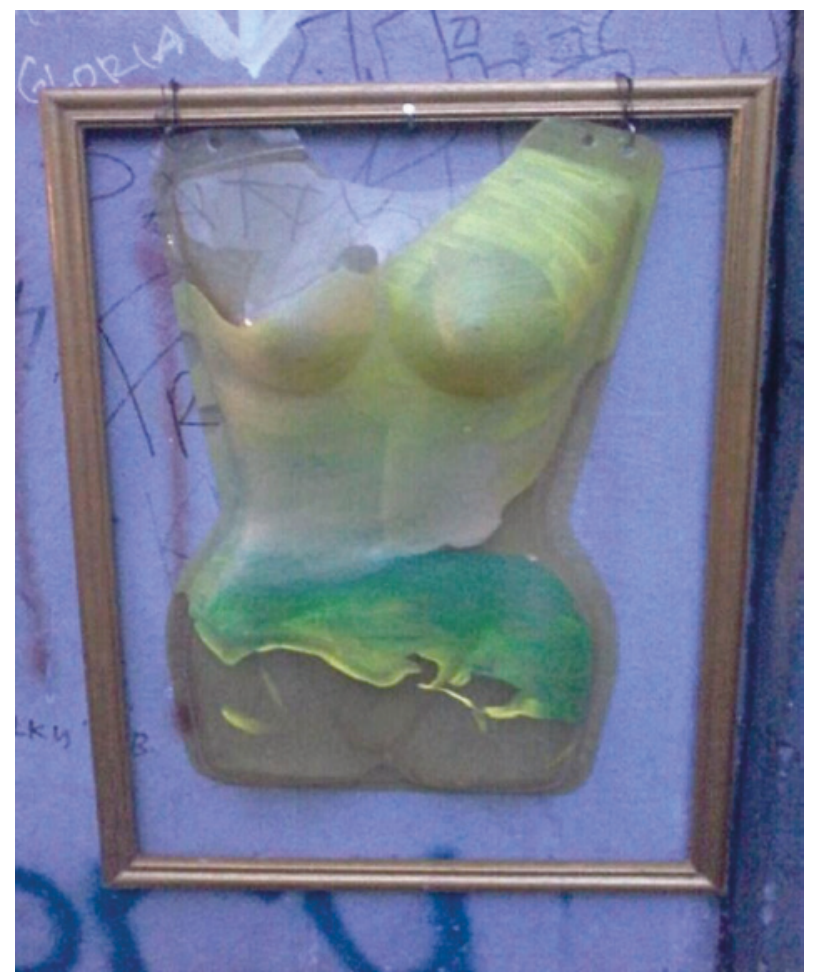

FIGURE 4.6 Artwork representing women's bodies commodified and victimised by violence SOURCE: PAB

forms of non-violent masculinities can become dominant and new forms of power dynamics and hierarchies emerge, providing, for example, certain men with social status linked to their post-conflict peacebuilding activities (Kunz, Myrttinen and Udasmoro, 2018). Art-for-peace projects seem particularly suitable for revealing this instability of masculinities.

Spaces for Women's Voices

As part of their objective to build peace, PAB initiatives aim to provide spaces for women's voices. РА B has sought to ensure that women are represented both through art and as members of the collective. This space is used by women artists for many purposes, including to express issues linked to women's bodies. Several РАB artworks incorporate questions of womanhood and femininity, as seen in Figure 4.6. 
This artwork, according to one of the women artists involved in its creation, is intended to represent women victims of violence, whose numbers increase every year in Ambon. It depicts a woman's body, damaged through an act of violence (interview with a woman artist member of PAB, 28 September 2020). The use of recycled elements of a plastic mannequin in this piece can also be interpreted as speaking to the commodification of the female body.

Here, РАв both creates space for depicting women's experiences of violence and seeks to prevent further violence against women. One member of PAB explains how art saved her life:

Because I almost got raped by a person on the street, and even till today it's hard for me to tell my family because of that moment, I had to pass through my life, and now it's fine. Because I think I open a new session of my life. I tell this story to so many people, so I think this is why I say art is saving my life.

Interview with a woman artist member of PAB, September 2020

The act of speaking up and creating artwork linked to issues of violence against women is also evident in works that refer to 'comfort women' (known locally as jugun ianfu), those women coerced into sexual servitude during the Japanese occupation of the Indonesian archipelago (Figure 4.7).

The violence experienced by comfort women was shared by thousands of women throughout Asia. The poem translates as:

Your samurais
Slicing my woven cloth
The red sun
You stain the memory
Comfort women
Hae
Hae
Hae

Although comfort women were taken from throughout Indonesia, the poem focuses predominantly on the experiences of the comfort women of Ambon, many of whom have survived until the present day. This is evident in the line mengiris kaun tenunku, as the woven cloth known as kaun tenun is identified with Ambon. Through such artwork, РAB uses art both as a way to heal trauma and as a social critique to denounce the practice of violence against women, thus contributing to the building of a more peaceful society. Here, we can again 


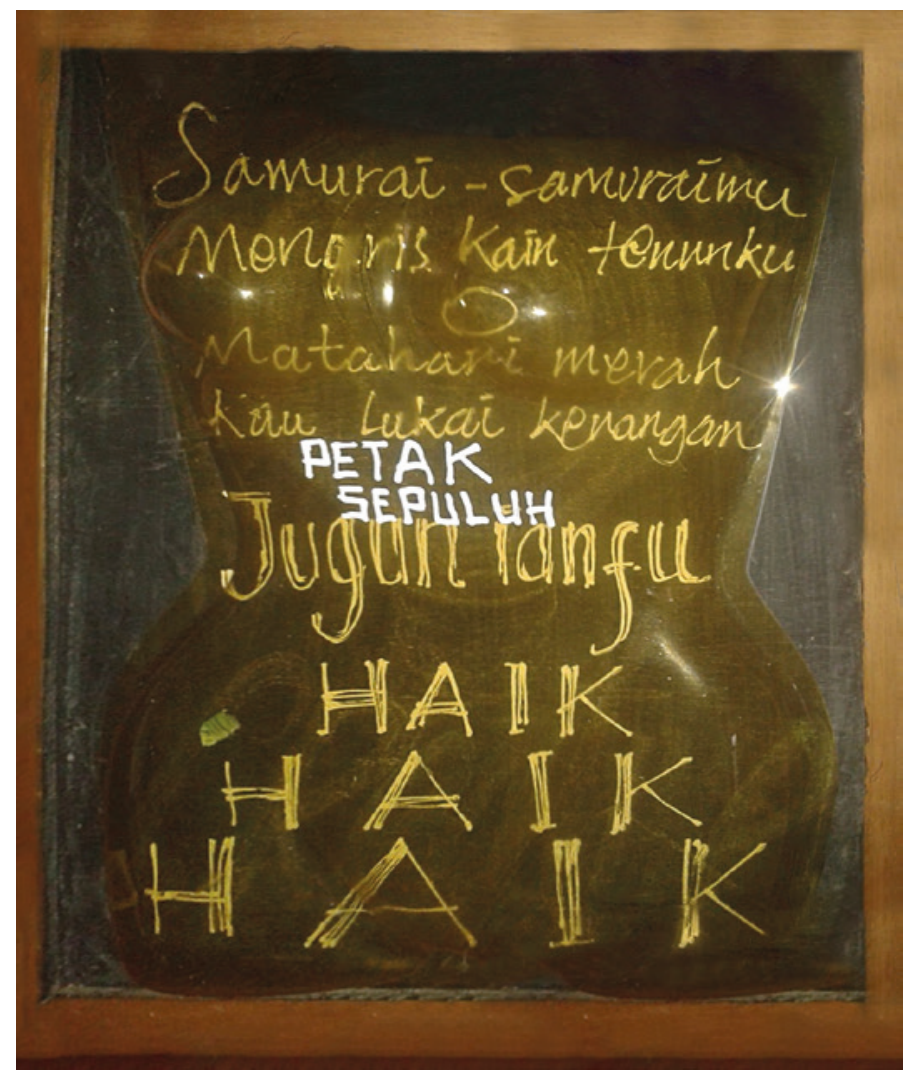

FIGURE 4.7 Poster criticising the sexual abuse of jugun ianfu (the 'comfort women' of Japanese colonisation)

SOURCE: PAB

observe how $\mathrm{PAB}$ art establishes associations between recent peacebuilding practices and overcoming the violence of colonial heritage. This illustrates how $\mathrm{PAB}$ art-for-peace initiatives reveal the complex ways in which gender logics intersect with ongoing colonial power dynamics.

Based on a shared wish to include more women, both male and female members of РАB have sought to provide spaces for women to narrate their own bodies and raise gender issues. Such spaces, in an Indonesian context, only became prominent after political reform had begun, thanks to the works of Ayu Utami and the Sastra Wangi movement (Marching, 2007). These spaces are intended to enable women to express their experiences in terms of their bodies, and of their sexualities. 


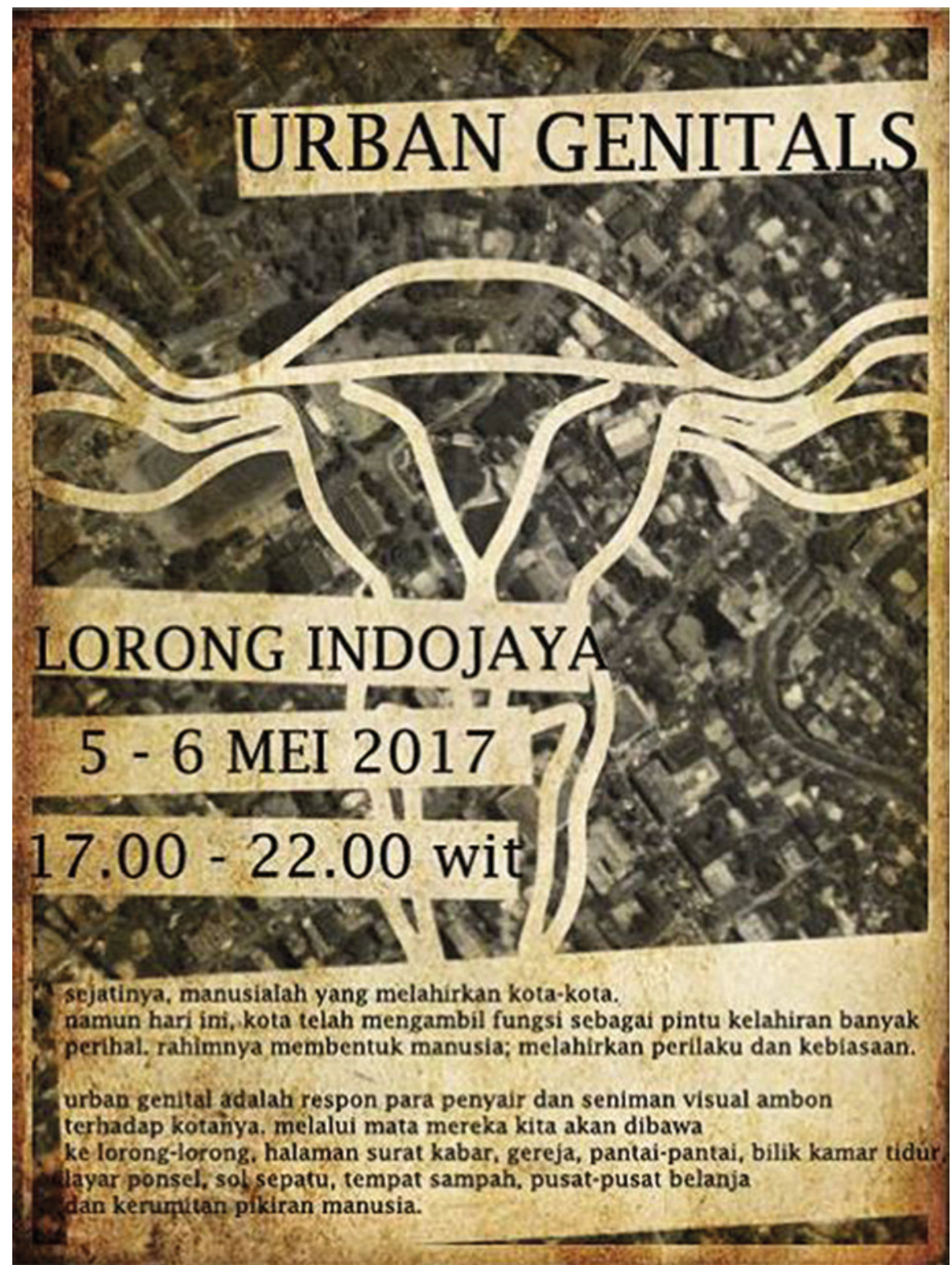

FIGURE 4.8 Poster for the Urban Genitals initiative SOURCE: PAB

The poster presented in Figure 4.8 was produced by one of the community's female members. A particular message is written on the poster: 
truly, it is humanity that births cities, but today, the city functions as a doorway to the birth of many things; its womb shapes humanity; births behaviours and habits.

Urban genital offers the responses of Ambon's poets and visual artists to their city, through their eyes we will be taken through its alleys, newspaper pages, churches, beaches, bedrooms, cellular phones, shoe soles, wastebins, shopping centres, and complex human minds.

Urban Genitals is an initiative by women artists. They link their critique of the problematic implications of urban planning and city development in Ambon to a critique of gender ideology regarding reproduction (interview with a woman artist member of $\mathrm{PAB}$, September 2020). They criticise how the authority of humans as those who control the cities is replaced by the authority of the cities, which control humans. Humans as logical subjects are replaced by cities, which become the subjects that control humans, via their economic activities, capitalism etc.

Here the space for women shows the ways in which women artists in PAB voice their experience of violence through the metaphor of the woman's body. Their art brings these often marginalised or stigmatised themes into a discussion about the complex and problematic situating of bodies in public spaces and peacebuilding. Remembering past gendered violences and associating them with today's gendered violences, these works emphasise the importance of art for gendered trauma healing. The artistic productions of women artists in $\mathrm{PAB}$ visibilise complex intersecting links between colonial heritage and recent conflicts and peacebuilding. They weave together the colonial past with today's cities as sites of capitalism and the complex forms of gendered violences involved. Mobilising art for healing trauma, building bridges, and expressing social critique, РАВ members build the bases for an inclusive peace. But art in this context not only contributes to peacebuilding, it is also an important expression of feminism and a form of female political agency, as has been shown by other scholars (Jauhola, 2016).

PAB is a community that creates a space in which Ambonese artists from various backgrounds can build peace. Its initiatives aim to strengthen the connection between different groups segregated through conflict, embrace differences, and build trust, friendships, and peaceful interactions. РАв activities mobilise art-for-peace in various ways: as artistic products, as 
interactive artistic processes, as training tools in art education, and as social critique. Our analysis shows the complex intersectional dynamics at play in these art-for-peace initiatives. They contribute to transforming masculinities into non-violent forms, and open spaces for women's voices and for raising awareness regarding violence against women and building peace. They also highlight the ways in which art-for-peace initiatives challenge dichotomies between conflict and peace, making an important contribution to peace and conflict studies beyond peacebuilding in Ambon. Our analysis allows us to show the various ways in which art-for-peace initiatives can contribute to inclusive peacebuilding. It also confirms that gender logics often work in intersection with other identity and power dynamics, in our context linked in particular to colonial heritage. Thus, our analysis reaffirms the importance, for inclusive peacebuilding, of addressing various forms of 'difference'. It also suggests that artwork lends itself particularly well to overcoming differences, healing trauma, building bridges and proposing new visions for peaceful societies.

Yet the example of РАВ also illustrates the tensions that art-for-peace initiatives can generate, for example when they reproduce gender stereotypes regarding different forms of art, notions of 'soft femininity', or violent imagery. Moreover, transformations of masculinity can sometimes produce contradictory results. Certain forms of non-violent masculinities can become dominant and new forms of power dynamics and hierarchies emerge, providing, for example, certain men with social statuses linked to their post-conflict peacebuilding activities. This illustrates the complexity of intersectional dynamics in art-for-peace initiatives.

It is important to remember that our critical reading aims to point to the open-ended politics of art-for-peace rather than offering fixed interpretations and meanings. We also do not aim to romanticise art. As we have seen, art can be used in many ways, including to fuel conflict and to build peace. As shown, in the context of Indonesia, art has a complex relationship with violence and conflict: it has been instrumentalised as a machinery of political violence and as a developmentalist tool. Future research could look into this complex relationship in more detail. Our analysis, meanwhile, shows that art-based initiatives can make important contributions to the building of peace. In particular, perhaps, when they emerge in a local context, as a local idea rather than as part of a government plan or other external intervention. Thus, it is important to take art-for-peace initiatives seriously as a form of peacebuilding and to continue investigating their intersectional implications. 


\section{Acknowledgements}

This chapter was enriched and strengthened by discussions with the team members of our collective research project on the Gender Dimensions of Social Conflict, Armed Violence and Peacebuilding: Mimidoo Achakpa, Henri Myrttinen, Joy Onyesoh, Elisabeth Prügl, Arifah Rahmawati and Christelle Rigual. We also thank Marjaana Jauhola and an anonymous reviewer for their constructive engagement with our article and their very helpful comments.

\section{References}

Andrä, C. (2020) 'Textiles Making Peace', The Palgrave Encyclopedia of Peace and Conflict Studies, pp. 1-11, Dor: 10.1007/978-3-030-11795-5_125-1.

Azca, M.N. (2006) 'In Between Military and Militia: The Dynamics of the Security Forces in the Communal Conflict in Ambon', Asian Journal of Social Science, 34(3), pp. 431-455, DOI: $10.1163 / 156853106778048588$.

Baker, C. (2019) 'Veteran Masculinities and Audiovisual Popular Music in PostConflict Croatia: A Feminist Aesthetic Approach to the Contested Everyday Peace', Peacebuilding, 7(2), pp. 226-242, DOI: 10.1080/21647259.2019.1588454.

Baker, J.S., F. Bjork, E. Bley, E. Eckhoff and E. Hubing (2019) 'A/R/T-Candidates Explore Intersectional Identities Through Art', Multicultural Perspectives, 21(3), pp. 159-166, DOI: 10.1080/15210960.2019.1659143.

Baljon, M.C. (2011) 'Wounded Masculinity: Transformation of Aggression for Male Survivors of Childhood Abuse', Person-Centered \& Experiential Psychotherapies, 10(3), pp. 151-164, DOI: 10.1080/14779757.2011.599512.

Berg, C.C. (1974) Penulisan Sejarah Jawa (Jakarta: Bhatara).

Bergh, A. and J. Sloboda (2010) 'Music and Art in Conflict Transformation: A review', Music and Arts in Action, 2(2), pp. 2-17, https://ore.exeter.ac.uk/repository/handle/ 10036/3946 (accessed on 13 April 2021).

Bertrand, J. (2004) Nationalism and Ethnic Conflict in Indonesia (Cambridge: Cambridge University Press).

Bhakti, I., N. Yanuarti and M. Nurhasim (2009) Military Politics, Ethnicity and Conflict in Indonesia, Working Paper No. 62 (Oxford: CRISE), https://assets.publishing.service. gov.uk/media/57ao8b7bed915d3cfdoood4a/wp62.pdf (accessed on 13 April 2021).

Bleiker, R. (2009) Aesthetics and World Politics (London: Palgrave Macmillan).

Bodden, M. (2010) Resistance on the National Stage: Theater and Politics in Late New Order Indonesia (Ohio: Ohio University Press). 
Bräuchler, B. (2019) 'From Transitional to Performative Justice: Peace Activism in the Aftermath of Communal Violence', Global Change, Peace \& Security, 31(2), pp. 201220, DOI: 10.108 o/14781158.2019.1585794.

Clery, T.N. (2014) 'Masculinities, Militarism, and the Construction of Gender in Contemporary Fiji: Performances of Parody and Subversion as Feminist Resistance ', Pacific Studies, 37(3), pp. 202-221.

Clery, T.N. (2013) The Art of Peace: Performative and Arts Based Peace Practices in Contemporary Fiji, PhD Thesis (Dunedin: University of Otago), https://ourarchive. otago.ac.nz/handle/10523/3739 (accessed on 13 April 2021).

Crenshaw, K. (1991) 'Mapping the Margins: Intersectionality, Identity Politics, and Violence Against Women of Color', Stanford Law Review, 43(6), pp. 1241-1299, DOI: $10.2307 / 1229039$.

Davis, A.Y. (2011) Women, Race, \& Class (New York: Knopf Doubleday Publishing Group). Enloe, C. (2000) Maneuvers: International Politics of Militarizing Women's Lives (Oakland: University of California Press).

Franger, G. (2014) 'Survival - Empowerment - Courage: Insights into the History and Developments of Peruvian Arpilleras', in M.Agosín(ed.) Stitching Resistance: Women, Creativity, and Fiber Arts (Kent: Solis Press), pp. 101-118.

Hancock, A.M. (2015) Intersectionality: An Intellectual History (Oxford: Oxford University Press).

Heryanto, A. (2008) Popular Culture in Indonesia: Fluid Identities in Post-Authoritarian Politics (London: Routledge).

Hill Collins, P. (1993) 'Toward a New Vision: Race, Class, and Gender as Categories of Analysis and Connection', Race, Sex and Class, 1(1), pp. 25-45.

Hooks, B. (2014) Feminist Theory: From Margin to Center (London: Routledge).

Indonesia Development Forum (2018) Paparisa Ambon Bergerak: Scraping Conflict Partition, Building Digital Economy in Maluku-Knowledge Center, https://indonesiadevelopmentforum.com/2019/knowledge-center/detail/6669-paparisaambon-bergerak-scraping-conflict-partition-building-digital-economy-in-maluku (accessed on 12 April 2021).

Irawanto, B. and T. Octastefani (2019) 'Film Dokumenter sebagai Katalis Perubahan Sosial Studi Kasus Ambon, Aceh dan Bali', Kawistara, 9(1), pp.107-119, DoI:10.22146/ kawistara.40986.

Irawanto, D.W., P.L. Ramsey and J.C. Ryan (2011) 'Challenge of Leading in Javanese Culture', Asian Ethnicity, 12(2), pp. 125-139, DOI: 10.1080/14631369.2011.571829.

Jauhola, M. (2016) “'Conversations in Silence”- Ceramic Installations Shaping Visual and Political Imagination of Gendered Tsunami and Conflict Reconstruction Landscapes in Aceh', in A.G. Altinay and A. Peto (eds.) Gendered War, Gendered Memories (London: Routledge), pp. 229-248. 
Jauhola, M. (2015) 'On "Being Bored”: Street Ehnography on Emotions in Banda Aceh After the Tsunami and Conflict', in L. Åhäll and T. Gregory (eds.) Emotions, Politics and War (Oxford and New York: Routledge), pp. 108-121.

Kappler, S. and N. Lemay-Hébert (2019) 'From Power-Blind Binaries to the Intersectionality of Peace: Connecting Feminism and Critical Peace and Conflict Studies', Peacebuilding, 7(2), pp. 16o-177, DoI: 10.108o/21647259.2019.1588456.

Kim, S., P. Kollontai and S. Yore (2016) Mediating Peace: Reconciliation Through Visual Art, Music and Film (Cambridge: Cambridge Scholars Publishing).

Kunz, R., H. Myrttinen and W. Udasmoro (2018) 'Preachers, Pirates and PeaceBuilding: Examining Non-Violent Hegemonic Masculinities in Aceh', Asian Journal of Women's Studies, 24(3), pp. 299-320, DOI: 10.108o/12259276.2018.1495348.

Labor, J.S. (2018) 'Role of Art Education in Peace Building Efforts Among Out-of-School Youth Affected by Armed Conflict in Zamboanga City, Philippines', Journal of International Development, 30(7), pp. 1186-1202, DOI: 10.1002/jid.3392.

Larasati, R.D. (2019) 'Reclaiming the Aesthetic of Women: De-colonizing Land Ownership', Cultural Studies, pp. 1-19, DOI: 10.1080/o9502386.2019.1585462.

Larasati, R.D. (2013) The Dance That Makes You Vanish: Cultural Reconstruction in PostGenocide Indonesia (Minneapolis: University of Minnesota Press).

Mandal, S.K. (2003) 'Creativity in the Protest: Art Workers and the Recasting of Politics and Society in Indonesia and Malaysia', in A. Heryanto and S.K. Mandal (eds.) Challenging Authoritarianism in Southeast Asia: Comparing Indonesia and Malaysia (London: Routledge).

Manuputti, R.E.E. (2018) Peranan Komunitas Paparisa Ambon Bergerak dalam Pengembangan Anak Muda di Kelurahan Ahusen Kecamatan Sirimau di Kota Ambon (Surabaya: Universitas Wijaya Kusuma).

Marching, S.T. (2007) 'Descriptions of Female Sexuality in Ayu Utami’s Saman', Journal of Southeast Asian Studies, 38(1), pp. 133-1454, Dor: 10.1080/oo043125.2014.11519272.

Marshall, L. (2014) 'Art as Peace Building'. Art Education, 67(3), pp. 37-43, DoI: 10.108o/ ooo43125.2014.11519272.

Mendoza, B. (2016) 'Coloniality of Gender and Power: From Postcoloniality to Decoloniality', in L.J. Disch and M.E. Hawkesworth (eds.) The Oxford Handbook of Feminist Theory (Oxford: Oxford University Press).

Muljana, S. (1979) Negarakertagama dan tafsir Sejarahnya (Jakarta: Bhatara Karya Aksara).

Nordstrom, C. (1997) A Different Kind of War Story (Philadelphia: University of Pennsylvania Press).

O’Rourke, K. (2002) Reformasi: The Struggle for Power in Post Soeharto Indonesia (New South Wales: Allen \& Unwin).

Parker, R. (1984) The Subversive Stitch: Embroidery and the Making of the Feminine (New York: I.B. Tauris). 
Premaratna, N., and R. Bleiker (2010) 'Art and Peacebuilding: How Theatre Transforms Conflict in Sri Lanka', in O.P. Richmond (ed.) Palgrave Advances in Peacebuilding (London: Palgrave Macmillan), pp. 376-391.

Pruitt, L.J. (2013) Youth Peacebuilding: Music, Gender, and Change, SUNY Series, Praxis: Theory in Action (New York: State University of New York Press).

Rigual, C., E. Prügl and R. Kunz (Forthcoming) 'Towards an Intersectionally Gendered Analysis of Conflict Dynamics', International Feminist Journal of Politics.

Rizzolo, L. and N. Schuler (2003) 'Art for Peace', Reclaiming Children and Youth, 11(4), pp. 247-249, http://reclaimingjournal.com/sites/default/files/journal-article-pdfs/ 11_4_Rizzolo.pdf (accessed on 13 April 2021).

Rohman, A. (2019) Framing, Friction, and the Continuity of Social Movements: The Case of the Ambonese Peace Movement in Indonesia (Nanyang: Nanyang Technological University), DOI: 10.32657/10220/47753.

Schroer-Hippel, M. (2016) Gewaltfreie Männlichkeitsideale: Psychologische Perspektiven auf Zivilgesellschaftliche Friedensarbeit (Wiesbaden: Springer-Verlag), DoI: 10.1007/ 978-3-658-12998-9.

Schulze, K.E. (2017) 'The 'Ethnic' in Indonesia's Communal Conflicts: Violence in Ambon, Poso and Sambas', Ethnic and Racial Studies, 40(12), pp. 2096-2114, DOI: $10.1080 / 01419870.2017 .1277030$.

Smith, C. (2017) Resilience and the Localisation of Trauma in Aceh, Indonesia (Singapore: Nus Press).

Stavrevska, E.B. and S. Smith (2020) 'Intersectionality and Peace', in The Palgrave Encyclopedia of Peace and Conflict Studies (Cham: Springer International Publishing), pp. 1-8, DOI:10.1007/978-3-030-11795-5_120-1.

Sudjatmiko, I.G. (2008) 'Communal Conflict, State Failure, and Peacebuilding: The Case of Ambon, Indonesia', Contributions to Conflict Management, Peace Economics and Development, 7, pp. 349-363, Do I: /10.1016/S1572-8323(o8)o7019-7.

Sulistiyono, S.T. and Y. Rochwulaningsih (2013) 'Contest for Hegemony: The Dynamics of Inland and Maritime Cultures Relations in the History of Java Island, Indonesia', Journal of Marine and Island Cultures, 2(2), pp.115-127, DOI:10.1016/j.imic.2013.10.002.

Tempo (2018) 'A Journey Across Differences', Tempo, June 20, https://magz.tempo.co/ $\mathrm{read} / 34545 / \mathrm{a}$-journey-across-differences (accessed on 12 April 2021).

Tidy, J. (2015) 'Gender, Dissenting Subjectivity and the Contemporary Military Peace Movement in Body of War', International Feminist Journal of Politics, 17(3), pp. 454472, DOI: $10.1080 / 14616742.2014 .967128$.

Trijono, L. (2002) 'Peran Komunikasi dalam Konflik dan Untuk Perdamaian' in L.S. Ispandriarno, T. Hanitzsch and M. Loeffelholz (eds.) Media, Militer, Politik: Crisis Communication: Perspektif Indonesia dan Internasional (Yogyakarta: Friedrich Ebert Stiftung \& Galang Press). 
Twarog, K.S. (2010) Performance and Trauma Recovery in Aceh, 5 th Annual International Workshop \& Expo on Sumatra Tsunami Disaster \& Recovery.

van Kinken, G. (2007) Communal Violence and Democratization in Indonesia: Small Town Wars (New York: Routledge).

Väyrynen, T. (2013) 'Keeping the Trauma of War Open in the Male Body: Resisting the Hegemonic Forms of Masculinity and National Identity in Visual Arts', Journal of Gender Studies, 22(2), pp. 137-151, DoI: 10.108o/o9589236.2012.745686.

Vickers, A. (2013) 'What is Contemporary Indonesian Art?', Inside Indonesia, 112, https://www.insideindonesia.org/what-is-contemporary-indonesian-art (accessed on 12 April 2021).

Wattimena, L. (2009) "Rumah Adat "Baileo" Interpretasi Budaya di Negeri HutumuriKecamata Leitimur Selatan Kota Ambon', Kapata Arkeologi, 5(8), pp. 2134, DOI: 10.24832/kapata.v5i8.107.

Wieringa, S. (2002) The Sexual Politics in Indonesia (New York: Palgrave and Institute of Social Science).

Wieringa, S. (1996) Sexual Metaphors in the Change from Sukarno's Old Order to Suharto's Old Order in Indonesia, Working Paper Series No 233, pp. 1-25 (The Hague: Institute of Social Studies).

Zelizer, C. (2003) The Role of Artistic Processes in Peace-Building in BosniaHerzegovina, Peace and Conflict Studies, 10(2), pp. 62-75, https://nsuworks.nova. edu/pcs/volio/iss2/4 (accessed on 13 April 2021). 